ISTIGHNA, Vol. 2, No 1, Januari 2019 P-ISSN 1979-2824

Homepage: http://e-journal.stit-islamic-village.ac.id/index.php/istighna

Brotojoyo Retnowati \& Agus Santoso

Peran Bimbel Ibu Bangsa Dalam Mendukumg Kesiapan Bersekolah Anak Usia Dini Dari Keluarga Kurang Mampu (Sebuah Study Kasus)

\title{
PERAN BIMBEL IBU BANGSA DALAM MENDUKUNG KESIAPAN BERSEKOLAH ANAK USIA DINI DARI KELUARGA KURANG MAMPU SEBUAH STUDY KASUS
}

\author{
Brotojoyo Retnowati \\ (retnobroto@gmail.com) \\ Dosen Sekolah Tinggi Ilmu Tarbiyah (STIT) Islamic Village Tangerang
}

\author{
Agus Santoso \\ (agus.santoso@uph.edu) \\ Dosen Universitas Pelita Harapan (UPH) Tangerang
}

\begin{abstract}
Children from poor families are facing great challenges as they are growing up. Limited resources, low-level parents' education, and environments have given impacts on how the families raise their children and prepare them for school. This research is to find out how a school readiness program initiated by Bimbel Ibu Bangsa for children of poor families at Kampung Gunung Sari can help them to get a quality education program and also to help parents implement effective parenting styles for the success of their children. A qualitative approach with a case-study model was used. The subject of this study consisted of 4 students out of the 16 students involved in the program. The data were collected by using participatory observations, home-visit notes, field notes, voice and visual recordings, and also by interviewing the parents and teachers. The validity of data was determined by triangulating and member-checking the data. The results of this research indicate that this program is quite able to be held with low budgets and will still be able to give quality education if the program is supported by the stakeholders in the community. The results also show that children and parents enrolled in this program gain many benefits shown by their adaptive parenting styles and children's modified behaviours for the upcoming school readiness and overall better quality of life.
\end{abstract}

Keywords: School Readiness, Early Childhood Education, Low-Income Family

\begin{abstract}
Abstrak: Anak-anak dari keluarga kurang mampu menghadapi tantangan dan kendala yang besar dalam tumbuh-kembangnya. Keterbatasan sumberdaya, rendahnya pendidikan orangtua, dan pengaruh lingkungan mewarnai pola asuh para orangtua dan bagaimana mereka mempersiapkan anak-anaknya untuk memasuki jenjang sekolah. Penelitian ini dilakukan untuk mengetahui bagaimana peran Bimbel Ibu Bangsa dapat membantu kesiapan bersekolah anak-anak usia dini dari keluarga kurang mampu di Kampung Gunung Sari agar mereka mendapatkan pendidikan yang berkualitas dan juga membantu orangtua dalam menerapkan pola asuh yang tepat bagi keberhasilan anak-anaknya. Penelitian ini menggunakan pendekatan kualitatif berjenis studi kasus. Sampel penelitian adalah 4 anak dari 16 siswa yang mengikuti program. Data diperoleh melalui observasi kelas, catatan home-visit, catatan lapangan, dokumentasi gambar dan suara, dan hasil wawancara walimurid dan guru. Keabsahan data dilakukan dengan
\end{abstract}


ISTIGHNA, Vol. 2, No 1, Januari 2019 P-ISSN 1979-2824

Homepage: http://e-journal.stit-islamic-village.ac.id/index.php/istighna

Brotojoyo Retnowati \& Agus Santoso

Peran Bimbel Ibu Bangsa Dalam Mendukumg Kesiapan Bersekolah Anak Usia Dini Dari Keluarga Kurang Mampu (Sebuah Study Kasus)

melakukan triangulasi data dan member-checking. Berdasarkan hasil penelitian ini, program bantuan kesiapan bersekolah dapat dilakukan dengan biaya rendah tetapi tetap berkualitas apabila dapat melibatkan berbagai pihak dalam masyarakat. Dari penelitian ini juga nampak bahwa anak-anak dan orangtua yang terlibat dalam program kesiapan bersekolah mendapat pengetahuan Nbaru tentang pola asuh yang tepat dan telah mendapat manfaat dari program ini, yang ditunjukkan oleh perubahan perilaku yang lebih baik dari siswa maupun orangtuanya demi mendukung kesiapan bersekolah dan kualitas hidup yang lebih baik.

Kata kunci: Program Kesiapan Bersekolah, Pendidikan Anak Usia Dini, Keluarga Kurang Mampu

\section{A. Pendahuluan}

Kemiskinan atau keadaan kurang mampu secara ekonomi dapat memunculkan banyak kesulitan dan hambatan. Ia membatasi akses sosial orang miskin atas semua kebutuhannya. Menjadi orang miskin berarti memiliki pilihan yang lebih terbatas, lebih sedikit, dan seringkali lebih rendah kualitasnya di bandingkan pilihan yang dimiliki kaum yang lebih mapan.

Dalam penelitian ini, penggunaan istilah "kurang mampu" secara alternatif akan diwakili juga dengan istilah "hidup berkekurangan"; "miskin"; "kurang beruntung"; atau "ekonomi lemah" tanpa mengurangi makna dari definisi "kurang mampu" yang akan diterangkan lebih jauh di dalam Landasan Teori.

Penelitian oleh Bank Dunia menyatakan bahwa anak-anak dari keluarga kurang mampu di Indonesia masih sedikit yang bisa mengenyam bangku Pendidikan Anak Usia Dini (PAUD), memiliki peluang besar untuk putus sekolah di bangku pendidikan menengah, atau kurang dapat berprestasi secara akadamis dibandingkan teman-temannya yang berasal dari kalangan ekonomi menengah ke $\operatorname{atas}^{106}$.

Anak-anak usia dini dari keluarga ekonomi lemah di Kampung Gunung Sari, Kelurahan Panunggangan Barat, Kota Tangerang, belum mendapatkan akses yang memadai dalam hal pendidikan anak usia dini yang berkualitas dan

${ }^{106}$ A. Hasan, et.al., "Early Childhood Education and Development in Poor Villages of Indonesia: Strong Foundations, Later Success," diakses pada 11 Mei 2017 dari https://openknowledge.worldbank.org/bitstreamhandle/10986/15799/784840PUB0EPI0000PUBD ATE06011020130.pdf?sequence $=1$ 
ISTIGHNA, Vol. 2, No 1, Januari 2019 P-ISSN 1979-2824

Homepage: http://e-journal.stit-islamic-village.ac.id/index.php/istighna

Brotojoyo Retnowati \& Agus Santoso

Peran Bimbel Ibu Bangsa Dalam Mendukumg Kesiapan Bersekolah Anak Usia Dini Dari Keluarga Kurang Mampu (Sebuah Study Kasus)

terjangkau secara finansial. Keterbatasan kemampuan ekonomi dan pengaruh lingkungan yang buruk menjadi tantangan bagi pengasuhan yang baik, selain parenting skills dari para orangtua memang juga masih rendah.

Berangkat dari kepedulian kepada anak-anak yang kurang mampu inilah akhirnya Bimbel Ibu Bangsa (BIB) memutuskan menerima siswa berusia dinidari usia tiga hingga enam tahun yang belum pernah "disekolahkan"-untuk dididik dalam sebuah program kesiapan bersekolah. Pertimbangan utamanya adalah ingin melihat bagaimana proses pelaksanaan program ini bila dilaksanakan, faktor apa saja yang mendukung, faktor apa saja yang menjadi kendala, dan juga ingin melihat bagaimana program dukungan kesiapan bersekolah ini dapat membantu perbaikan pola asuh dan peningkatan kompetensi siswa. Lebih jauh, pernyataan Barnett-bahwa program pendidikan bagi anakanak usia dini dari keluarga yang kurang mampu memiliki arti yang besar dan bisa menjadi penentu dan pembeda antara gagal atau sukses; pendidikan umum atau khusus; menjadi anak yang "baik" atau terlibat kenakalan remaja; hingga menjadi drop-out atau berhasil lulus dari sekolah menengah atas-menjadi motivasi tersendiri dalam penerapannya ${ }^{107}$.

Dalam menjalankan penelitian ini permasalahan yang muncul dapat diidentifikasi sebagai berikut: pemenuhan kebutuhan gizi pada anak usia dini yang masih belum sesuai standar empat sehat lima sempurna; kebiasaan jajan sembarangan dan makan junk food pada anak usia dini; kebiasaan membiarkan anak usia dini untuk tidur larut malam dan bangun tidur kesiangan; kondisi kesehatan anak usia dini yang rentan sakit; kurangnya perhatian orangtua terhadap masalah kebersihan dan kesehatan gigi anak; tingkat pendidikan orangtua dari keluarga kurang mampu yang masih rendah; kurangnya pemahaman orangtua dalam mendukung kesiapan bersekolah anak usia dini; kurangnya kesadaran orangtua terhadap pentingnya pendidikan anak usia dini; banyaknya jumlah anak usia dini yang belum memiliki akta kelahiran atau tercatat dalam Kartu Keluarga; pola asuh orangtua yang belum sesuai dengan tuntutan pertumbuhan dan

\footnotetext{
${ }^{107}$ Steven Barnett, "Long-Term Effects of Early Childhood Programs on Cognitive and School Outcomes", $\quad$ diakses pada $11 \quad$ Mei 2017 dari https://www.princeton.edu/futureofchildren/publications/docs/05_03_01.pdf
} 
ISTIGHNA, Vol. 2, No 1, Januari 2019 P-ISSN 1979-2824

Homepage: http://e-journal.stit-islamic-village.ac.id/index.php/istighna

Brotojoyo Retnowati \& Agus Santoso

Peran Bimbel Ibu Bangsa Dalam Mendukumg Kesiapan Bersekolah Anak Usia Dini Dari Keluarga Kurang Mampu (Sebuah Study Kasus)

perkembangan anak; kecenderungan orangtua untuk menerapkan pola asuh serba permisif dan sekedar ikut-ikutan seperti yang diterapkan oleh tetangga/lingkungan di sekitarnya; kurangnya pendampingan dan pengawasan orangtua terhadap anak ketika bermain dengan sebayanya; kecenderungan untuk memanjakan anak dengan mainan; kecenderungan orangtua untuk tidak membatasi waktu bermain anak; kecenderungan terjadinya Kekerasan dalam Rumah Tangga (KDRT), baik secara verbal atau pun fisik, yang dilakukan oleh orangtua/orang dewasa pada anak; kebiasaan membuang sampah sembarangan; ketiadaan buku bacaan di rumah bagi anak usia dini; kebiasaan bergunjing dan saling iri dalam kehidupan bertetangga; dan kurangnya lembaga pendidikan bagi anak usia dini yang berkualitas tetapi berbiaya rendah/terjangkau bagi keluarga kurang mampu.

Dari segala permasalahan tersebut, maka ditetapkanlah batasan masalah penelitian sebagai berikut: 1) pola asuh orangtua yang belum sesuai dengan tuntutan pertumbuhan dan perkembangan anak; 2) kurangnya kesadaran orangtua terhadap pentingnya pendidikan anak usia dini; 3) kurangnya pemahaman orangtua dalam mendukung kesiapan bersekolah anak usia dini; dan 4) kurangnya lembaga pendidikan bagi anak usia dini yang berkualitas tetapi berbiaya rendah/terjangkau bagi keluarga kurang mampu.

Secara umum, penelitian ini bertujuan untuk mengetahui pertumbuhan dan perkembangan anak-anak usia dini dari keluarga kurang mampu dan membantu kesiapannya memasuki jenjang sekolah formal; melihat hasil yang nampak (observable behavior) dari pelaksanaan program kesiapan bersekolah yang sudah dijalankan; mengetahui kendala yang dialami oleh orangtua dalam mendukung program kesiapan bersekolah Bimbel Ibu Bangsa (BIB); dan mengidentifikasi langkah-langkah strategis yang dapat dilakukan untuk mengatasi kendala yang dijumpai dalam pelaksanaan program kesiapan bersekolah.

Dengan demikian, rumusan masalah penelitian ini adalah sebagai berikut: 1) Bagaimana pertumbuhan dan perkembangan anak-anak usia dini dari keluarga kurang mampu terkait dengan kesiapannya masuk sekolah?; 2) Bagaimana hasil yang nampak (observable behavior) dari pelaksanaan program kesiapan bersekolah yang sudah dilakukan?; 3) Sejauh mana orangtua mengalami kesulitan 
ISTIGHNA, Vol. 2, No 1, Januari 2019 P-ISSN 1979-2824

Homepage: http://e-journal.stit-islamic-village.ac.id/index.php/istighna

Brotojoyo Retnowati \& Agus Santoso

Peran Bimbel Ibu Bangsa Dalam Mendukumg Kesiapan Bersekolah Anak Usia Dini Dari

Keluarga Kurang Mampu (Sebuah Study Kasus)

dalam mendukung program kesiapan bersekolah?; 4) Bagaimana langkah strategis yang dapat dilakukan untuk mengatasi kesulitan dalam pelaksanaan program kesiapan bersekolah?

\section{B. Landasan Teori}

World Health Organization (WHO) mendefinisikan anak usia dini sebagai fase krusial dalam pertumbuhan dan perkembangan yang berlangsung dalam delapan tahun pertama kehidupan anak yang diyakini dapat memengaruhi perkembangan sepanjang hidup seseorang ${ }^{108}$. Menurut Permendikbud No 137 Tahun 2014 pasal 1 ayat 10, pendidikan anak usia dini dilaksanakan untuk membantu pertumbuhan dan perkembangan jasmani dan rohani agar anak memiliki kesiapan dalam memasuki pendidikan lebih lanjut ${ }^{109}$.

Seorang anak yang telah memiliki kompetensi, pengetahuan, dan sikap yang diperlukan untuk berhasil di sekolah, pendidikan lanjut, dan kehidupan nantinya, dianggap telah memiliki kesiapan bersekolah ${ }^{110}$. Besarnya perhatian terhadap kesiapan bersekolah ini bahkan telah menginspirasi The National Education Goals Panel (NEGP) pada tahun 1991 untuk menetapkan bahwa mulai tahun 2000, (ditargetkan) semua anak akan memasuki sekolah dalam keadaan siap belajar $^{111}$.

Kesiapan bersekolah bukanlah sesuatu yang terjadi begitu saja pada anak. Anak usia dini yang berada pada masa golden years ini perlu perawatan, kasih sayang, stimulasi yang tepat, dukungan yang konsisten, dan pemenuhan kebutuhan dasar lain agar mantap memasuki jenjang sekolah. Faktor dukungan dari lingkungan ekologisnya sangat diperlukan pada masa-masa ini.

\footnotetext{
${ }^{108}$ World Health Orgaization (WHO), "Early Childhood Development and Disability: a Discussion Paper", diakses pada 18 November 2017 dari http://apps.who.int/iris/bitstream/10665/75355/1/9789241504065_eng.pdf

${ }^{109}$ Kementerian Pendidikan dan Kebudayaan RI, "Peraturan Menteri Pendidikan dan Kebudayaan RI No.137 Tahun 2014 Tentang Standar Nasional Pendidikan Anak Usia Dini”, diakses pada 01 Desember 2017 dari http://paud.kemdikbud.go.id /resource/peraturan-uu/

${ }^{110}$ ECLKC. "School Readiness", diakses pada 24 Februari 2018 dari https://eclkc.ohs.acf.hhs.gov/school-readiness

${ }^{111}$ Pamela High \& The Committee on Early Childhood, Adoption, and Dependent Care and Council on School Health. "School Readiness", e-journal diakses pada 10 Februari 2018 dari http://pediatrics.aap-Publications.org/content/121/4/e1008.full
} 
ISTIGHNA, Vol. 2, No 1, Januari 2019 P-ISSN 1979-2824

Homepage: http://e-journal.stit-islamic-village.ac.id/index.php/istighna

Brotojoyo Retnowati \& Agus Santoso Peran Bimbel Ibu Bangsa Dalam Mendukumg Kesiapan Bersekolah Anak Usia Dini Dari Keluarga Kurang Mampu (Sebuah Study Kasus)

Dalam buku yang berjudul The Irreducible Needs of Children: What Every Child Must Have to Grow, Learn, and Flourish, Brazelton dan Greenspan (2000) menyatakan bahwa ada tujuh kebutuhan dasar anak yang harus terpenuhi demi tumbuh-kembangnya yang optimal, yaitu: 1) hubungan kelekatan dengan orangtua atau pengasuh yang berlangsung secara intensif, interaktif, dan suportif; 2) keteraturan, keamanan, dan perlindungan fisik; 3) bimbingan yang disesuaikan dengan keunikan anak; 4) pendidikan yang disesuaikan dengan tahapan tumbuhkembang anak; 5) harapan, struktur, dan batasan-batasan; 6) lingkungan yang stabil dan mendukung dan budaya yang konsisten; dan 7) masa depan yang terlindung. Tujuh poin kebutuhan dasar di atas, apabila terpenuhi dengan baik, akan menjadi fondasi yang kokoh dan menjadi faktor utama penentu keberhasilan bersekolah $^{112}$.

The National Education Goals Panel (NEGP) menetapkan kesiapan bersekolah anak dapat dilihat melalui 5 aspek perkembangan, yaitu: 1) kesehatan fisik dan perkembangan motorik; 2) perkembangan sosial dan emosional; 3) pendekatan terhadap belajar; 4) perkembangan bahasa; dan 5) perkembangan kognitif dan pengetahuan umum ${ }^{113}$. Di Indonesia, lima indikator ini disesuaikan dengan nilai-nilai yang dianut bangsa Indonesia dan dituangkan dalam Permendikbud No. 137 Tahun 2014 tentang Standar Nasional Pendidikan Anak Usia Dini. Di dalamnya, salah satunya mencakup tentang Standar Tingkat Pencapaian Perkembangan Anak (STPPA) yang memuat unsur-unsur nilai agama dan moral, kemampuan berpikir, kemampuan berbahasa, kemampuan sosialemosional, kemampuan fisik-motorik, serta apresiasi terhadap seni.

Berkaitan dengan pendidikan anak usia dini dari keluarga kurang mampu, pembelajaran model Maria Montessori (1870-1952) yang telah dikenal masyarakat dunia dan memandang bermain sebagai "work tasks" yang harus dikerjakan persis seperti telah dicontohkan oleh guru, sebenarnya didesain untuk

\footnotetext{
${ }^{112}$ T. Berry Brazelton dan Stanley I. Greenspan, The Irreducible Needs of Children: What Every Child Must Have to Grow, Learn, and Flourish, (Cambridge: Perseus, 2000)

${ }^{113}$ Child Trends. "Early School Readiness," artikel diakses pada 25 Februari 2018 dari https://www.child-trends.org/indicators/early-school-readiness/
} 
ISTIGHNA, Vol. 2, No 1, Januari 2019 P-ISSN 1979-2824

Homepage: http://e-journal.stit-islamic-village.ac.id/index.php/istighna

Brotojoyo Retnowati \& Agus Santoso Peran Bimbel Ibu Bangsa Dalam Mendukumg Kesiapan Bersekolah Anak Usia Dini Dari Keluarga Kurang Mampu (Sebuah Study Kasus)

anak-anak usia 4-7 tahun dari keluarga kurang mampu ${ }^{114}$. Keluarga kurang mampu yang dimaksud, yang menjadi subyek dalam penelitian ini, telah sesuai dengan definisi kurang mampu yang disampaikan oleh Menteri Perencanaan Pembangunan Nasional (PPN) Bambang Brodjonegoro, yang menyatakan bahwa penghasilan penduduk yang menjadi garis batas kemiskinan adalah sebesar Rp 361.990,00 per September $2016^{115}$.

Merujuk pada teori sistem ekologis Uric Bronfenbrenner (1917-2005), kondisi hidup dalam keluarga dan masyarakat padat penduduk yang miskin dan cenderung terisolir menimbulkan beberapa kondisi mengkhawatirkan bagi anakanak. Secara umum, ana-anak dari keluarga kurang mampu akan menghadapi kendala-kendala sebagai berikut: gizi yang buruk; pengasuhan yang tidak optimal karena orangtua terlalu sibuk mencari nafkah sehingga tidak memiliki cukup waktu untuk memperhatikan anaknya; kurangnya stimuli perkembangan; kurangnya keteladanan dalam menuntut ilmu; terpapar pada pengaruh buruk media tanpa pengawasan dan bimbingan; isu-isu kesehatan yang membahayakan; memiliki peluang besar terpapar pada kekerasan dalam rumah tangga (KDRT) maupun perundungan dari lingkungan sosial; dan tidak/kurang memiliki peluang untuk mendapatkan fasilitas pendidikan yang berkualitas.

\section{Metode Penelitian}

Penelitian ini pada dasarnya dilaksanakan dengan pendekatan kualitatif. Nkwi, Nyamongo, dan Ryan menyatakan bahwa "Qualitative research involves any research that uses data that do not indicate ordinal values" ${ }^{116}$. Dengan demikian, pendekatan riset ini lebih banyak menggunakan sumber data berupa teks (hasil observasi, hasil wawancara, catatan lapangan, dokumentasi), rekaman visual (berupa foto atau video), dan suara (rekaman suara).

\footnotetext{
${ }^{114}$ Michael L. Henniger, Teaching Young Children: an Introduction, ed. 4, (New Jersey: Pearson, 2009), h. 61

${ }^{115}$ Yoga Sukmana, “Berapa Penghasilan yang Masuk Kategori Miskin di Indonesia?”, artikel diakses pada 08 Februari 2018 dari http://ekonomi.kompas.com/read /2017/07/06/18364 0226/berapa.penghasilan.yang.masuk.kategori.miskin.di.indonesia

${ }^{116}$ Paul Nchoji Nkwi, et.al, "Field Research Into Socio-cultural Issues: Methodological Guidelines", (International Center for Applied Social Sciences, Research, and Training, 2001), h. 1
} 
ISTIGHNA, Vol. 2, No 1, Januari 2019 P-ISSN 1979-2824

Homepage: http://e-journal.stit-islamic-village.ac.id/index.php/istighna

Brotojoyo Retnowati \& Agus Santoso Peran Bimbel Ibu Bangsa Dalam Mendukumg Kesiapan Bersekolah Anak Usia Dini Dari Keluarga Kurang Mampu (Sebuah Study Kasus)

Mengingat penelitian ini bersifat unik dan ingin mengetahui lebih mendalam tentang program intervensi, maka jenis penelitian yang dipilih adalah studi kasus. Yin $(1996,18)$ menyatakan bahwa "studi kasus adalah suatu inkuiri empiris yang menyelidiki fenomena di dalam konteks kehidupan nyata, bilamana batas-batas antara fenomena dan konteks tak tampak dengan tegas, dan di mana multisumber bukti dimanfaatkan". 117

Subyek penelitian ini adalah empat anak usia dini dengan rentang usia tiga hingga tujuh tahun yang berasal dari Kampung Gunungsari, Kelurahan Panunggangan Barat, Kecamatan Cibodas, Kota Tangerang. Subyek hanya dipilih empat anak, yang terdiri dari dua anak laki-laki dan dua anak perempuan dari total 16 siswa PAUD karena menunjukkan tipikal karakteristik anak-anak yang biasa ditangani oleh program intervensi anak usia dini dan cukup mewakili keadaan teman-temannya yang lain, yaitu: berasal dari keluarga kurang mampu, memiliki keterbatasan sumber daya belajar dan memiliki masalah keluarga (troubled family) yang berimbas pada pengasuhan dan dukungan terhadap kesiapan bersekolah. Keempat siswa tersebut adalah V, P, A, dan S.

Penelitian yang dilakukan pada tanggal 2 Februari - 9 Maret 2017 ini berlokasi di dua tempat yang berdekatan, yaitu: tempat bimbingan belajar Bimbel Ibu Bangsa yang beralamat di Kompleks Villa Ilhami, Jl. Mina XVII, Blok K1/16-17, Kelurahan Panunggangan Barat, Kecamatan Cibodas, Kota Tangerang; dan Home Visit dilaksanakan di tempat tinggal masing-masing siswa di Kampung Gunungsari, Kelurahan Panunggangan Barat, Kecamatan Cibodas, Kota Tangerang. Jarak antara lokasi pendidikan non-formal (Bimbel) dan rumah peserta program berada dalam jangkauan radius 100-500 meter dan masih dapat ditempuh dengan berjalan kaki.

Teknik pengumpulan data dilaksanakan dengan cara: observasi, wawancara, dan studi dokumen. Instrumen pengumpulan data yang digunakan, di antaranya adalah pedoman observasi; pedoman wawancara; dokumen hasil belajar anak; Kartu Kembang Anak (KKA); catatan lapangan; dan foto dan rekaman suara.

\footnotetext{
${ }^{117}$ Robert K. Yin, Studi Kasus: Desain dan Metode, (Jakarta: Raja Grafindo Persada, 1996), h. 18
} 
ISTIGHNA, Vol. 2, No 1, Januari 2019 P-ISSN 1979-2824

Homepage: http://e-journal.stit-islamic-village.ac.id/index.php/istighna

Brotojoyo Retnowati \& Agus Santoso Peran Bimbel Ibu Bangsa Dalam Mendukumg Kesiapan Bersekolah Anak Usia Dini Dari Keluarga Kurang Mampu (Sebuah Study Kasus)

Proses pengumpulan data penelitian ditempuh dalam beberapa tahapan sebagai berikut: 1) persiapan lokasi pembelajaran/ruang kelas, alat-alat permainan edukatif, pemindahan jadwal pembelajaran, dan pembuatan rencana pembelajaran/lesson plans; 2) pengkondisian siswa dan orangtua terhadap jadwal dan peraturan kelas; 3) observasi terhadap siswa dan orangtua dengan menggunakan instrumen penilaian kegiatan siswa dan pedoman observasi; 4) Home visit dilakukan ke rumah masing-masing siswa dengan perjanjian terlebih dahulu atau insidental apabila siswa sedang sakit atau keluarganya sedang ditimpa musibah; 5) Wawancara di luar jadwal Home Visit, misalnya ketika tak sengaja berjumpa di jalan atau toko atau ketika peneliti sedang melewati rumah siswa dan diminta berhenti untuk bercakap-cakap sebentar; dan 6) merangkum dan menganalisis data.

Data yang terkumpul dari hasil observasi, wawancara, dan dokumentasi dianalisis dengan metode analisis data kualitatif model Miles dan Huberman yang menyatakan ada tiga proses yang harus dilalui dalam menganalisis data, yaitu: 1) reduksi data; 2) model data (data display); 3) penarikan/verifikasi kesimpulan ${ }^{118}$.

Berhubungan dengan keabsahan data, peneliti terus melakukan triangulasi data antara data yang didapatkan dari hasil observasi, hasil wawancara, hasil dokumentasi, maupun catatan lapangan, baik selama masa penelitian maupun setelah data terkumpul, sekaligus juga melakukan member-checking di antara para subyek penelitian.

Penelitian kualitatif melalui pendekatan studi kasus ini memiliki beberapa keterbatasan, di antaranya adalah: keterlibatan peneliti dalam pembelajaran dan interaksi langsung dengan subyek penelitian dan keluarganya sedikit-banyak dapat memengaruhi obyektifitas peneliti dalam memahami subyek beserta aspekaspek yang diteliti; keterbatasan waktu dalam pelaksanaan penelitian; rendahnya tingkat sosial-ekonomi keluarga dan taraf pendidikan orangtua menjadi tantangan tersendiri bagi peneliti dalam menjalin komunikasi dan memahami keadaan subyek penelitian; dan pengalaman peneliti yang masih sangat terbatas sehingga

${ }^{118}$ Emzir, Analisis Data : Metodologi Penelitian Kualitatif, (Jakarta: Rajawali Pers, 2012), h. $129-135$ 
ISTIGHNA, Vol. 2, No 1, Januari 2019 P-ISSN 1979-2824

Homepage: http://e-journal.stit-islamic-village.ac.id/index.php/istighna

Brotojoyo Retnowati \& Agus Santoso

Peran Bimbel Ibu Bangsa Dalam Mendukumg Kesiapan Bersekolah Anak Usia Dini Dari Keluarga Kurang Mampu (Sebuah Study Kasus)

sangat memengaruhi bagaimana peneliti mengumpulkan, menganalisis, dan menyajikan data.

\section{Paparan Data dan Temuan Penelitian}

Siswa pertama, V, adalah anak laki-laki berusia 3 tahun 6 bulan dan merupakan anak kelima dari enam bersaudara. Ia terkategori kurang gizi dan tumbuh kembangnya masih belum sesuai dengan standar tumbuh kembang anak seusianya. $\mathrm{V}$ berasal dari keluarga pemulung yang hanya memiliki sedikit mainan lusuh dan tak memiliki buku bacaan satu pun. Ibunya buta huruf dan ayahnya yang hanya tamatan SD sangat minim hadir di rumah dan terlibat dalam pengasuhan. V sangat jarang menggosok gigi karena tidak memiliki sikat gigi sendiri. Ibu sering mengalami migraine dan stress karena hubungan yang kurang harmonis dengan mertua dan tetangga. $\mathrm{V}$ cukup rajin hadir di kelas kecuali bila terhalang sakit atau hujan lebat karena ketiadaan payung di rumah. Penilaian pencapaian Tingkat Pertumbuhan dan Perkembangan Anak (TPPA) V di kelas menunjukkan peningkatan pesat dari waktu ke waktu.

Siswa kedua, P, adalah anak laki-laki berusia 3 tahun 10 bulan dan merupakan anak kedua dari dua bersaudara. Ia terkategori kurang gizi dan tumbuh kembangnya masih belum sesuai dengan standar tumbuh kembang anak seusianya. P tinggal bersama ayah dan keluarga besar dari ayah, dengan bibi berperan sebagai pengganti ibu kandung yang sudah bercerai dari ayahnya. Ayah dan keluarga besar cenderung memanjakan $\mathrm{P}$ dengan menuruti apa pun kemauan $\mathrm{P}$ dan membelikannya berbagai mainan hingga gadget meskipun dari hasil hutang. Sayangnya, $\mathrm{P}$ tidak memiliki satu pun buku bacaan di rumah. $\mathrm{P}$ cenderung manja dan agresif. Ia akan memukul siapa saja yang tidak menuruti kemauannya. P sangat jarang menggosok gigi, akibatnya ia sering sakit gigi. P cukup rajin hadir di kelas kecuali bila terhalang sakit atau hujan lebat. Penilaian pencapaian Tingkat Pertumbuhan dan Perkembangan Anak (TPPA) P di kelas menunjukkan peningkatan pesat dari waktu ke waktu.

Siswa ketiga, A, adalah anak perempuan berusia 3 tahun 8 bulan dan merupakan anak ketiga dari tiga bersaudara. Ia terkategori kurang gizi dan tumbuh kembangnya masih belum sesuai dengan standar tumbuh kembang anak 
ISTIGHNA, Vol. 2, No 1, Januari 2019 P-ISSN 1979-2824

Homepage: http://e-journal.stit-islamic-village.ac.id/index.php/istighna

Brotojoyo Retnowati \& Agus Santoso Peran Bimbel Ibu Bangsa Dalam Mendukumg Kesiapan Bersekolah Anak Usia Dini Dari Keluarga Kurang Mampu (Sebuah Study Kasus)

seusianya. A tinggal bersama ibu yang single parent, kakak, dan nenek-kakeknya. Ia juga bertetangga dengan keluarga besar ibunya. A adalah anak yang sangat mandiri dan terbiasa mengatur jadwal hidup semaunya sendiri karena cenderung dituruti dan dibiarkan oleh ibu dan keluarganya. A sangat gemar jajan, bermain di luar hampir sepanjang waktu, tidur larut malam, dan bangun kesiangan. Nilai kehadiran A di kelas masih sangat kurang yang disebabkan oleh kebiasaannya bangun kesiangan. Penilaian pencapaian Tingkat Pertumbuhan dan Perkembangan Anak (TPPA) A di kelas menunjukkan peningkatan pesat dari waktu ke waktu.

Siswa keempat, S, adalah anak perempuan berusia 6 tahun 9 bulan dan merupakan anak keempat dari enam bersaudara. Ia adalah kakak dari V. S terkategori cukup gizi. Sebagaimana V, S berasal dari keluarga pemulung yang hanya memiliki sedikit mainan lusuh dan tak memiliki buku bacaan selain bukubuku yang didapatkan dari PAUD BIB. S rajin ikut mengaji sore di lingkungan rumah. S sangat jarang menggosok gigi karena tidak memiliki sikat gigi sendiri. S sering terserang demam. Di kelas, $\mathrm{S}$ cukup rajin hadir kecuali bila terhalang sakit atau hujan lebat karena ketiadaan payung di rumah. Penilaian pencapaian Tingkat Pertumbuhan dan Perkembangan Anak (TPPA) V menunjukkan peningkatan pesat.

\section{E. Pembahasan Hasil Penelitian}

Untuk memudahkan dalam membahas hasil penelitian ini, maka urutannya akan disesuaikan dengan rumusan masalah sebagai berikut:

\section{E.1. Bagaimana pertumbuhan dan perkembangan anak-anak usia dini dari keluarga kurang mampu terkait dengan kesiapannya masuk sekolah?}

Dilihat dari aspek kebutuhan dasar anak sesuai rumusan Brazelton dan Greenspan (2000) dalam bukunya The Irreducible Needs of Children: What Every Child Must Have to Grow, Learn, and Flourish, anak-anak yang mengikuti program kesiapan bersekolah ini belum terpenuhi kebutuhan dasarnya dengan baik, terutama yang berkaitan dengan hubungan kelekatan dengan orangtua atau pengasuh yang berlangsung secara intensif, interaktif, dan suportif; keteraturan, konsistensi, dan perlindungan fisik; bimbingan yang disesuaikan dengan keunikan anak; harapan, struktur, dan batasan-batasan. 
ISTIGHNA, Vol. 2, No 1, Januari 2019 P-ISSN 1979-2824

Homepage: http://e-journal.stit-islamic-village.ac.id/index.php/istighna

Brotojoyo Retnowati \& Agus Santoso Peran Bimbel Ibu Bangsa Dalam Mendukumg Kesiapan Bersekolah Anak Usia Dini Dari Keluarga Kurang Mampu (Sebuah Study Kasus)

Pertumbuhan dan perkembangan anak-anak usia dini dari keluarga kurang mampu belum sesuai dengan standar Kartu Menuju Sehat (KMS), Kartu Kembang Anak (KKA) dan Tingkat Pertumbuhan dan Perkembangan Anak (TPPA) yang ditetapkan dalam Permendikbud No. 137 Tahun 2014 sebagaimana telah disebutkan dalam profil individu siswa dan capaian TPPA.

Secara umum dapat disebutkan bahwa pertumbuhan dan perkembangan anak-anak usia dini dari keluarga kurang mampu ini berlangsung sebagai berikut: 1) dari aspek agama dan moral, anak-anak mulai memahami agama yang dianutnya, mulai terbiasa mengucapkan salam, menjawab salam, dan menirukan doa pendek, meskipun masih harus sering diingatkan dan dicontohkan; 2) dari aspek fisik-motorik, anak-anak sangat menikmati permainan-permainan yang menguatkan motorik kasarnya, seperti: melempar bola ke dalam keranjang, berjinjit, melompat, senam, atau berlarian dikejar "Serigala", dan mereka juga sangat antusias mengikuti kegiatan Montessori Time yang lebih banyak dirancang untuk menguatkan motorik halusnya; 3) dari aspek kognitif, anak-anak belajar untuk fokus selama kegiatan Montessori Time dan berusaha melakukan kegiatan seperti yang dicontohkan; 4) bahasa, anak-anak pada awalnya memiliki kemampuan berbahasa yang rendah, karena mereka mengalami kesulitan mengidentifikasi emosi yang dirasakan, belum terbiasa mengekspresikan perasaan atau menceritakan pengalaman secara verbal, dan belum terpapar pada budaya belajar dan membaca. Pembiasaan membaca buku cerita dengan muatan karakter atau pengenalan emosi di BIB dan di rumah, selain keteladanan dalam berbahasa yang baik dan sopan, telah memengaruhi pola komunikasi dan interaksi di dalam kelas menjadi lebih menyenangkan; 5) sosial-emosional, anak-anak yang belum terbiasa dengan batasan dan aturan, pada awalnya mengalami kesulitan dalam mengikuti peraturan di kelas. Namun, dengan pengulangan dan berlalunya waktu, anak-anak mulai dapat menerima dan mengikuti peraturan, menunjukkan kemandirian ke toilet, mulai belajar lebih menahan diri apabila marah, dan dengan dorongan yang tepat mulai mau mengakui kesalahan dan meminta maaf; 6) seni, anak-anak belajar bernyanyi bersama, mengenal berbagai macam tepuk, menggerakkan tubuh sesuai irama, melukis, berkreasi dengan berbagai bahan, 
ISTIGHNA, Vol. 2, No 1, Januari 2019 P-ISSN 1979-2824

Homepage: http://e-journal.stit-islamic-village.ac.id/index.php/istighna

Brotojoyo Retnowati \& Agus Santoso Peran Bimbel Ibu Bangsa Dalam Mendukumg Kesiapan Bersekolah Anak Usia Dini Dari Keluarga Kurang Mampu (Sebuah Study Kasus)

juga belajar memupuk rasa bangga pada hasil karya sendiri dan menghargai hasil karya orang lain. Hampir seluruh kegiatan yang berkaitan dengan seni sangat jarang dilakukan oleh anak-anak usia dini ini di lingkungan tempat tinggalnya.

\section{E.2. Bagaimana hasil yang nampak (observable behavior) dari pelaksanaan program kesiapan bersekolah yang sudah dilakukan?}

Hasil yang nampak (observable behaviour) dari pelaksanaan program kesiapan bersekolah ini dapat dipaparkan sebagai berikut: 1) keterampilan hidup/life skills anak berkembang; 2) anak makin tertib dalam mengatur waktu tidur di malam hari dan bangun di pagi hari; 3) anak memiliki rasa tanggung jawab untuk membereskan mainannya sendiri; 4) dapat mengurangi kebiasaan jajan pada anak; 5) anak lebih bisa menahan diri bila menginginkan sesuatu; 6) anak memiliki semangat belajar; 7) anak mulai menampakkan ketertarikan “memegang" pensil; 8) anak sudah mulai mau menggosok gigi; 9) anak lebih mudah paham apabila diajak berkomunikasi; 10) anak mulai menyukai membaca buku; 11) anak sudah mulai bisa berhitung; 12) terjadi perkembangan yang beragam pada perolehan kompetensi anak dalam aspek agama dan nilai-nilai moral, fisik-motorik, kognitif, bahasa, sosial-emosional, dan seni; dan 13) orangtua/walimurid mendapatkan pengetahuan baru tentang pola asuh yang tepat bagi anak-anaknya.

Hasil tersebut bercerita banyak tentang efektivitas metode pembelajaran Montessori dan penerapan aturan Developmentally Appropriate Practices (DAP) dari The National Association for the Education of Young Children (NAEYC) dalam pembelajaran di kelas dan adaptasi pengasuhan yang dilakukan orangtua di rumah demi mendukung kesiapan bersekolah anaknya.

\section{E.3. Sejauh mana orangtua mengalami kesulitan dalam mendukung program kesiapan bersekolah?}

Lima ranking tertinggi kendala yang dihadapi orangtua dalam mendukung program kesiapan bersekolah anak adalah sebagai berikut: 1) peran keluarga besar; 2) keuangan terbatas; 3) hubungan bertetangga; 4) isu keteraturan atau konsistensi pengasuhan; dan 5) karakter anak yang kurang dipahami oleh orangtua. 
ISTIGHNA, Vol. 2, No 1, Januari 2019 P-ISSN 1979-2824

Homepage: http://e-journal.stit-islamic-village.ac.id/index.php/istighna

Brotojoyo Retnowati \& Agus Santoso Peran Bimbel Ibu Bangsa Dalam Mendukumg Kesiapan Bersekolah Anak Usia Dini Dari Keluarga Kurang Mampu (Sebuah Study Kasus)

E.4. Bagaimana langkah strategis yang dapat dilakukan untuk mengatasi kesulitan dalam pelaksanaan program kesiapan bersekolah?

Langkah-langkah strategis yang dapat dilakukan untuk mengatasi kesulitan dalam pelaksanaan program kesiapan bersekolah adalah: 1) melakukan pendekatan dan menjalin hubungan yang erat dengan keluarga siswa dan semua pihak yang terlibat langsung dengan pengasuhan anak; 2) memberikan penyuluhan untuk orangtua/walimurid sesuai dengan permasalahan unik yang dihadapi siswa dan orangtuanya dengan mendatangkan orang-orang yang memang ahli di bidangnya, seperti dokter umum, dokter gigi, pakar parenting, dan lainlain; 3) menyediakan sesi konseling atau konsultasi permasalahan pribadi bagi orangtua; 4) mencontohkan akhlaq yang baik dalam berinteraksi dengan siswa, sesama guru, maupun dengan orangtua; 5) melatih kedisiplinan dan kebiasaan baik pada siswa; 6) memberikan bantuan berupa uang, bahan makanan, dan obatobatan dalam kondisi yang dinilai perlu untuk dibantu; 7) banyak berdiskusi dan sharing dengan guru-guru yang lain tentang pendidikan yang lebih efektif dan solusi dalam memecahkan masalah yang dihadapi dalam menyiapkan siswa agar siap sekolah.

\section{F. Kesimpulan, Implikasi dan Saran}

Dalam penelitian ini, tumbuh kembang anak-anak dari keluarga kurang mampu nampak mengalami kendala pada awalnya, baik dari segi pertumbuhan fisik kasat mata yang dapat diukur dan ditimbang (BB/TB), hingga lingkuplingkup perkembangan yang meliputi aspek agama dan moral, kognitif, fisikmotorik, bahasa, sosial-emosional, maupun seni. Ketertinggalan capaian Tingkat Pertumbuhan dan Pertumbuhan Anak (TPPA) disiasati dengan menyediakan aktivitas berbasis program Montessori, sedangkan keadaan kurang asupan gizi pada siswa diatasi melalui penyediaan sarapan pagi bagi seluruh siswa.

Hasil yang nampak (observable behaviour) dari program kesiapan bersekolah ini terhadap anak-anak adalah keterampilan hidup/life skills anak berkembang; anak makin tertib dalam mengatur waktu tidur di malam hari dan bangun di pagi hari; anak memiliki rasa tanggung jawab untuk membereskan mainannya sendiri; dapat mengurangi kebiasaan jajan pada anak; lebih bisa 
ISTIGHNA, Vol. 2, No 1, Januari 2019 P-ISSN 1979-2824

Homepage: http://e-journal.stit-islamic-village.ac.id/index.php/istighna

Brotojoyo Retnowati \& Agus Santoso

Peran Bimbel Ibu Bangsa Dalam Mendukumg Kesiapan Bersekolah Anak Usia Dini Dari Keluarga Kurang Mampu (Sebuah Study Kasus)

menahan diri bila menginginkan sesuatu; memiliki semangat belajar; mulai menampakkan ketertarikan "memegang" pensil; sudah mulai mau menggosok gigi; anak lebih mudah paham apabila diajak berkomunikasi; mulai menyukai membaca buku; anak sudah mulai bisa berhitung; terjadi perkembangan yang beragam pada perolehan kompetensi anak dalam aspek agama dan nilai-nilai moral, fisik-motorik, kognitif, bahasa, sosial-emosional, dan seni; dan orangtua/walimurid mendapatkan pengetahuan baru tentang pola asuh yang tepat bagi anak-anaknya.

Kendala yang dihadapi orangtua dalam menerapkan pola asuh yang tepat bagi anak meliputi banyak hal. Namun, lima kendala terbesarnya adalah yang berhubungan dengan peran keluarga besar dalam pengasuhan yang tanpa disadari malah berdampak negatif pada pembentukan karakter anak; keuangan yang terbatas; hubungan dengan tetangga yang kurang harmonis; isu keteraturan/konsistensi yang berhubungan dengan batasan, aturan, dan konsekuensi atas perbuatan anak, dan karakter anak yang terbentuk oleh pola asuh dan pengaruh lingkungan ekologisnya yang kurang menguntungkan.

Langkah-langkah strategis yang dapat dilakukan untuk mengatasi kendala tersebut adalah dengan melakukan pendekatan dan menjalin hubungan yang erat dengan keluarga siswa dan semua pihak yang terlibat langsung dengan pengasuhan anak; memberikan penyuluhan parenting bagi semua pihak yang terlibat langsung dalam pengasuhan anak; menyediakan sesi konseling atau konsultasi permasalahan pribadi bagi orangtua; Mencontohkan akhlaq yang baik dalam berinteraksi dengan siswa, sesama guru, maupun dengan orangtua; melatih kedisiplinan dan kebiasaan baik pada siswa; memberikan bantuan berupa uang, bahan makanan, dan obat-obatan dalam kondisi yang dinilai perlu untuk dibantu; dan banyak berdiskusi dan sharing dengan guru-guru BIB yang lain tentang strategi pendidikan yang lebih efektif dan solusi dalam memecahkan masalah yang dihadapi dalam menyiapkan siswa siap masuk sekolah.

Hasil penelitian tentang program kesiapan bersekolah anak usia dini ini membawa beberapa implikasi dalam pelaksanaan pembelajaran di kelas maupun dalam menjangkau keluarga secara langsung, yaitu: perbaikan pembelajaran di 
ISTIGHNA, Vol. 2, No 1, Januari 2019 P-ISSN 1979-2824

Homepage: http://e-journal.stit-islamic-village.ac.id/index.php/istighna

Brotojoyo Retnowati \& Agus Santoso

Peran Bimbel Ibu Bangsa Dalam Mendukumg Kesiapan Bersekolah Anak Usia Dini Dari Keluarga Kurang Mampu (Sebuah Study Kasus)

kelas, baik dari aspek perencanaan, pelaksanaan, hingga penilaian; memastikan setiap guru memahami tentang program dan tujuan pembelajaran agar dapat bersama-sama bersinergi untuk memberikan pengalaman belajar yang bermakna bagi siswa; menjalin hubungan lebih erat dengan walimurid dan semua pihak yang yang terlibat dalam pengasuhan anak secara langsung, sebab mereka adalah lingkungan di mana anak lebih lama menghabiskan waktunya dibandingkan dengan jam pembelajaran di kelas yang sangat terbatas; dan melibatkan peran serta masyarakat dari berbagai profesi untuk aktif terlibat dalam kegiatan program kesiapan bersekolah ini.

Berdasarkan hasil penelitian, berikut ini adalah saran-saran yang dapat dijadikan bahan pertimbangan untuk semua pihak yang terlibat dalam penelitian secara langsung, pihak-pihak lain yang terkait, maupun untuk penelitian selanjutnya.

Saran-saran berikut ini diniatkan untuk semua pihak yang berkeinginan melaksanakan program kesiapan bersekolah di wilayahnya, yaitu: perencanaan program kesiapan bersekolah ini akan lebih berhasil baik apabila dilakukan jauhjauh hari dan dimatangkan sebelum program berjalan; kunjungan ke rumah siswa setidaknya perlu dilakukan tiga kali, yakni sebelum program berjalan, pada saat program berlangsung, dan pada akhir program untuk melakukan evaluasi; pertemuan pembelajaran di kelas sebaiknya dilakukan minimal tiga kali dalam seminggu untuk memaksimalkan hasil yang nampak; pembelajaran di kelas akan lebih baik lagi apabila dirancang dengan pendekatan tematik, sehingga siswa memiliki pemahaman yang utuh mengenai apa yang dilakukan dan dipelajari selama di kelas; program yang diberikan gratis bukan berarti program yang asalasalan dan tidak konsisten. Konsistensi dalam pembelajaran dan penanaman nilainilai bagi siswa dan keluarganya semestinya diupayakan untuk berjalan berkesinambungan dan mengalami peningkatan kualitas dari waktu ke waktu; dan bekerja dengan hati menjadi syarat utamanya, karena program ini memadukan antara sisi pendidikan dan sisi kemanusiaan.

Selanjutnya, bagi para orangtua siswa program kesiapan bersekolah hendaknya memeperhatikan saran-saran berikut ini: mengetahui dengan pasti 
ISTIGHNA, Vol. 2, No 1, Januari 2019 P-ISSN 1979-2824

Homepage: http://e-journal.stit-islamic-village.ac.id/index.php/istighna

Brotojoyo Retnowati \& Agus Santoso Peran Bimbel Ibu Bangsa Dalam Mendukumg Kesiapan Bersekolah Anak Usia Dini Dari Keluarga Kurang Mampu (Sebuah Study Kasus)

alasan melibatkan anak usia dini dalam program ini; segera melakukan penyesuaian pada pola asuh apabila tidak konsisten dengan program kesiapan bersekolah yang telah diajarkan kepada anak di kelas; orangtua hendaknya tidak pernah berhenti belajar walau berapa pun usianya; mendidik anak adalah mendidik manusia dan kemanusiaan, maka harus dilakukan dengan hati dan diniatkan sebagai bentuk ibadah kepada Allah SWT.

Bagi kaum akademisi yang notabene adalah kaum yang memiliki modal dasar ilmu dan rasa kepedulian terhadap dunia pendidikan, maka saran-saran yang dapat disampaikan adalah sebagai berikut: hendaknya peduli untuk melihat dari dekat masalah pendidikan yang dihadapi anak-anak dan keluarga di lingkungan warga kurang mampu dan temukan solusi untuk membantu mereka.

Yang terakhir, penelitian mengenai program kesiapan bersekolah bagi anakanak usia dini dari keluarga kurang mampu di Indonesia masih belum banyak dilakukan. Maka penelitian di bidang ini dalam bentuk studi eksperimental atau pun evaluasi program hendaknya dilaksanakan di masa depan.

\section{Daftar Pustaka}

Awanih, walimurid. Interview by Author, 17 May 2017, Tangerang. Audio recording. Bimbel Ibu Bangsa, Tangerang.

Badan Kependudukan dan Keluarga Berencana Nasional (BKKBN), Kamus Istilah Kependudukan. Home page on-line. Available from http://babel.bkkbn.go.id /data / Documents/kamus-Istilah.doc (accessed 22 November 2017).

Badan Pusat Statistik (BPS), Pendataan Program Perlindungan Sosial 2011. Home page on-line. Available from catalog.ihsn.org/index.php/catalog/4020/down load/54630, (accessed 01 December 2017).

-, Karakteristik Rumah Tangga Miskin dan Rumah Tangga Tidak Miskin. Home page on-line. Available from https://www.bps.go.id/linkTableDinamis/view/id/908 (accessed 11 May 2017). 
ISTIGHNA, Vol. 2, No 1, Januari 2019 P-ISSN 1979-2824

Homepage: http://e-journal.stit-islamic-village.ac.id/index.php/istighna

Brotojoyo Retnowati \& Agus Santoso

Peran Bimbel Ibu Bangsa Dalam Mendukumg Kesiapan Bersekolah Anak Usia Dini Dari Keluarga Kurang Mampu (Sebuah Study Kasus)

—, Kemiskinan dan Ketimpangan: Konsep. Home page on-line. Available from https://www.bps.go.id/Subjek/view/id/23\#subjekViewTab1|accordiondaftars ubjek1 (accessed 11 May 2017).

Barnett, Steven, Long-Term Effects of Early Childhood Programs on Cognitive and School Outcomes. Available from https://www.princeton.edu/futureofchildren/publications/docs/05_03_01.pdf (accessed 11 May 2017).

Baumrind, Diana. (1967). Child Care Practices Anteceding Three Patterns Of Preschool Behavior. Genetic Psychology Monographs, 75(1), 43-88. Available from http://persweb.wabash.edu/facstaff/hortonr/articles\%20for\%20class/baumrin d.pdf (accessed 01 December 2017).

Berk, Laura E., Development Through the Lifespan: Dari Prenatal sampai Remaja (Transisi Menjelang Dewasa), 5th ed. Boston: Pearson Education, 2010. Edisi terjemahan. Yogyakarta: Pustaka Pelajar, 2012.

Bronfenbrenner's Ecological Theory. Home page on-line. Available from http://sarahkaye.com/feiv/DissertationAbstracts/bronfenbrenner+ecological +theory+of+development+essayshark-4945 (accessed 07 December 2017).

Chan, BMY, "Challenges to Parenting: The Local Scene". Proceeding (2004). Available from http://www.hkjpaed.org/pdf/2004;9;182-184.pdf, (accessed 01 December 2017).

Child Trends. "Early School Readiness," Child Trends Online. Home page online. Available from https://www.childtrends.org/indicators/early-schoolreadiness/; Internet; accessed 25 February 2018.

ECLKC. "School Readiness," Head Start ECLKC. Home page on-line. Available from https://eclkc.ohs.acf.hhs.gov/school-readiness; Internet; accessed 24 February 2018.

Emzir, Analisis Data : Metodologi Penelitian Kualitatif. Jakarta: Rajawali Pers, 2012.

Ernawati, Een, guru. Interview by Author, 22 November 2017, Tangerang. Audio recording. Bimbel Ibu Bangsa, Tangerang. 
ISTIGHNA, Vol. 2, No 1, Januari 2019 P-ISSN 1979-2824

Homepage: http://e-journal.stit-islamic-village.ac.id/index.php/istighna

Brotojoyo Retnowati \& Agus Santoso

Peran Bimbel Ibu Bangsa Dalam Mendukumg Kesiapan Bersekolah Anak Usia Dini Dari Keluarga Kurang Mampu (Sebuah Study Kasus)

Evans, Gary, The Environment of Childhood Poverty. American Psychologist, Vol. 59, No. 2, 77-92. New York: 2004. Available from http://people.auc.ca/brodbeck/4007/Arti

cle9.pdf, (accessed 01 December 2017).

Hasan, A., M. Hyson, and M.C. Chang, Early Childhood Education and Development in Poor Villages of Indonesia: Strong Foundations, Later Success. Home page on-line. Available from https://openknowledge.worldbank.org/bitstream handle/1098 6/15799/784840PUB0EPI0000PUBDATE06011020130.pdf? sequence=1 (accessed 11 May 2017).

Henniger, Michael L., Teaching Young Children: an Introduction. 4th ed. New Jersey: Pearson, 2009.

Herdiansyah, Haris, Wawancara, Observasi, dan Focus Group Sebagai Instrumen Penggalian Data Kualitatif. Jakarta: Rajawali Pers, 2013.

High, Pamela, and The Committee on Early Childhood, Adoption, and Dependent Care and Council on School Health. "School Readiness", Journal of $\begin{array}{llll}\text { Pediatrics } & 121 & \text { (2008). }\end{array}$ http://pediatrics.aappublications.org/content/121/4/e1008.full (accessed 10 February 2018)

Indriyanti, Yuli, guru. Interview by Author, 22 November 2017, Tangerang.

Audio recording. Bimbel Ibu Bangsa, Tangerang.

Iyat, walimurid. Interview by Author, 18 May 2017, Tangerang. Audio recording.

Bimbel Ibu Bangsa, Tangerang.

Kementerian Pendidikan dan Kebudayaan RI, Peraturan Menteri Pendidikan dan Kebudayaan RI No.137 Tahun 2014 Tentang Standar Nasional Pendidikan Anak Usia Dini. Home page on-line. Available from http://paud.kemdikbud.go.id /resource/peraturan-uu/ (accessed 01 December 2017).

Medina, Raihana A., guru. Interview by Author, 22 November 2017, Tangerang. Audio recording. Bimbel Ibu Bangsa, Tangerang. 
ISTIGHNA, Vol. 2, No 1, Januari 2019 P-ISSN 1979-2824

Homepage: http://e-journal.stit-islamic-village.ac.id/index.php/istighna

Brotojoyo Retnowati \& Agus Santoso

Peran Bimbel Ibu Bangsa Dalam Mendukumg Kesiapan Bersekolah Anak Usia Dini Dari Keluarga Kurang Mampu (Sebuah Study Kasus)

Melania, Neni, walimurid. Interview by Author, 14 March 2017, Tangerang. Audio recording. Bimbel Ibu Bangsa, Tangerang.

Persiapan Kompetensi/Kapasitas untuk Transisi ke Sekolah. Diterjemahkan dari Building Competency/Capacity for Transition to School. Home page online. Available

from

https://www.unicef.org/earlychildhood/files/Child2Child_ConceptualFrame work_FINAL(1).pdf (accessed 23 February 2018)

Ramey, Craig and Sharon Ramey, "Early Intervention and Early Experience," Journal of American Psychologist, Vol. 53, No. 2, 109-120 (1998). [ejournal]

https://static.vtc.vt.edu/media/documents/179_Early_intervention_and_Ear ly_in-tervention_and_early_experience.pdf (accessed 28 November 2017).

Roslina, guru. Interview by Author, 22 November 2017, Tangerang. Audio recording. Bimbel Ibu Bangsa, Tangerang.

Sacks, Vanessa, 5 Ways Neighborhoods of Concentrated Disadvantage Harm Children. Home page on-line. Available from https://www.childtrends.org/ child-trends-5/five-ways-neighborhoods-concentrated-disadvantage-harmchildren/; Internet; accessed 23 February 2018.

Sekretariat Kabinet Republik Indonesia, BPS: Per September 2016, Jumlah Penduduk Miskin Indonesia Berkurang 0,25 Juta. Home page on-line. Available from http://setkab.go.id/bps-per-september-2016-jumlahpenduduk-miskin-indonesia-bekurang-025-juta/ (accessed May 2017).

Shonkoff, Jack, dan Samuel Meisels, Early Childhood Intervention: The Evolution of a Concept, 2nd ed., Cambridge; Cambridge University Press, 2000. Available from https://www.bc.edu/content/dam/files/schools/lsoe/pdf/EICS/EarlyChildhoo dInterventionTheEvolutionofaConcept.pdf (accessed 28 November 2017).

Sukmana, Yoga, Berapa Penghasilan yang Masuk Kategori Miskin di Indonesia?. Home page on-line. Available from http://ekonomi.kompas.com/read /2017/07/06/18364 
ISTIGHNA, Vol. 2, No 1, Januari 2019 P-ISSN 1979-2824

Homepage: http://e-journal.stit-islamic-village.ac.id/index.php/istighna

Brotojoyo Retnowati \& Agus Santoso

Peran Bimbel Ibu Bangsa Dalam Mendukumg Kesiapan Bersekolah Anak Usia Dini Dari Keluarga Kurang Mampu (Sebuah Study Kasus)

0226/berapa.penghasilan.yang.masuk.kategori.miskin.di.indonesia.

(accessed 08 February 2018)

Tim Nasional Percepatan Penanggulangan Kemiskinan (TNP2K), Program Penanggulangan Kemiskinan di Indonesia. Home page on-line. Available from http://www.tnp2k.go.id/id/program/sekilas/ (accessed 11 May 2017).

Yin, Robert K., Studi Kasus: Desain dan Metode. Jakarta: Raja Grafindo Persada, 1996.

Vargas-Baron, Emily, Ulf Janson, and Natalia Mufel, Early Childhood Intervention, Special Education and Inclusion: A Focus on Belarus, UNICEF publications (2009). [e-journal]. Available from https://www.unicef.org/eca/Belarus_English. pdf (accessed 27 November 2017).

Wardle, Francis, Introduction to Early Childhood Education: A Multidimensional Approach to Child-Centered Care and Learning. Boston: Pearson Education, 2003

World Health Orgaization (WHO), Early Childhood Development and Disability: a Discussion Paper, Genewa: WHO, 2012. Available from http://apps.who.int/ｉris/bitstream/10665/75355/1/9789241504065_eng.pdf (accessed 28 November 2017).

Wortham, Sue, Early Childhood Curriculum:Developmental Bases for Learning and Teaching, 4th ed. New Jersey: Pearson-Merrill Prentice Hall, 2006. 